\title{
Implantação de uma brinquedoteca no setor pediátrico do Hospital Municipal Santana de Carandaí, Minas Gerais: um relato de experiência
}

\author{
Mateus Marcolin, Graziele Carolina de Almeida Marcolin, Alan Rodrigues de Souza, Amanda \\ Conrado Silva Barbosa
}

\begin{abstract}
Resumo
A palavra "hospes" advinda do latim significa "lugar em que há pessoas hospedadas", ou seja, no âmbito hospitalar as pessoas podem ser vistas como hóspedes. Contudo há um pequeno diferencial, pois no caso do hospital as pessoas ali hospedadas encontram-se em tratamento. Logo, o hospital é visto como parte integrante de um sistema coordenado de saúde, o qual apresenta a função de propiciar assistência médica preventiva e curativa, inclusive em serviços que sejam extensíveis à família. Sendo assim, a humanização do atendimento propiciado às pessoas hospitalizadas normalmente deve ser assumido pelos profissionais que fazem parte de um determinado sistema. No caso do setor de pediatria, os profissionais devem clamar pela melhora no atendimento da criança hospitalizada, respeitando suas vivências e valorizando o ser humano que acompanha tal criança no momento de internação. Com isso, o objetivo do relato é analisar a importância da implantação de uma brinquedoteca hospitalar no Hospital Municipal Santana de Carandaí - MG. Para tanto, a metodologia utilizada foi o relato de experiência, o qual ocorreu por meio de observação direta dos autores no processo de implantação da brinquedoteca no hospital em análise. Os resultados demonstram que a brinquedoteca deve ser vista como um acervo selecionado no âmbito hospitalar, o qual deve ser reconhecido e respeitado por todos os setores e profissionais atuantes em um hospital. Além disso, este ambiente deve ser visto como um espaço de bem estar e acolhimento da criança, uma vez que nele é propiciado o brincar livre da mesma fazendo que esta exponha seus anseios, vivências e sentimentos envoltos à hospitalização. Na brinquedoteca hospitalar deve-se existir uma perspectiva de atuação multidisciplinar, priorizando, através da atuação de profissional específico, o brincar livre e terapêutico da criança. Contudo, a brinquedoteca não deve ser utilizada para induzir comportamentos colaborativos ou para favorecer a execução de certos procedimentos. A própria criança se mostrará mais colaborativa quanto mais relaxada e alegre se apresentar diante do processo de internação. Assim, foi observado durante a implantação da brinquedoteca que o processo de hospitalização traz consigo diversos problemas, onde dentre eles destaca-se o rompimento com as relações familiares e com as atividades cotidianas. Esses fatores mostraram a necessidade da brinquedoteca no contexto hospitalar, pois além de coletar os principais sentimentos e anseios desta criança em meio ao brincar neste local, ainda é possível trabalhar diretivamente suas demandas mais peculiares com vistas ao seu desenvolvimento típico. Logo, a inserção de atividades lúdicas no ambiente hospitalar pode auxiliar no tratamento da criança que padece de internação de longo prazo, uma vez que através destas atividades a criança consegue demonstrar seus anseios, frustrações, bem como emoções advindas com o processo de internação. A utilização do lúdico, neste contexto, recebe um teor de humanização, auxiliando a criança a lidar com experiências estressantes e ampliando seu campo perceptual. Assim, observa-se que através do tratamento complementar realizado na brinquedoteca, as crianças podem apresentar um maior desenvolvimento, restringindo possíveis rompimentos advindos do processo de internação.
\end{abstract}

Descritores: Brinquedoteca; Setor Pediátrico; Desenvolvimento. 